FACTA UNIVERSITATIS

Series: Physical Education and Sport, Vol. 18, No 2, 2020, pp. 465 - 474

https://doi.org/10.22190/FUPES190515044D

Narrative review article

\title{
PSYCHOLOGICAL ASPECTS OF MOTIVATION IN SPORT ACHIEVEMENT
}

UDC 159.9.01

796.015 .01

\section{Dušanka Đurović1, Aleksandra Aleksić Veljković², Tanja Petrović1}

${ }^{1}$ Faculty of Sport and Tourism, Educons University from Sremska Kamenica, Novi Sad, Serbia

${ }^{2}$ Faculty of Sport and Physical Education, University of Niš, Niš, Serbia

\begin{abstract}
The aim of this paper is to point out the importance of motivation in sport achievement and to describe the psychological aspect of motivation, as one of the most important psychological factors for success. Motivation theories give definitions of terms and previous knowledge of different authors, and the second part of this paper gives the most commonly used techniques: Goal settings, cognitive restructuring, and imagination, and how to apply them. When it comes to motivation in sports, some important concepts and some of the most important interventions for motivating athletes presented in this paper can be analyzed in the psychological training of athletes. Special attention given to the importance and the role of trainers in the process of motivating athletes emphasizes psychology as a key factor in sport achievement.
\end{abstract}

Key words: Psychology, Motivation, Theories, Athletes, Trainers, Success in Sport

\section{INTRODUCTION}

In the psychology of sport, motivation is emphasized as a key factor in sporting success (Gould, Dieffenbach, \& Moffett, 2002), but it is also believed that it contributes to the persistence of athletes during exercises and competitions (Wilson \& Rodgers, 2004, according to Vallerand, 2007). Both athletes and trainers point out that motivation is one of the most important psychological factors for success in sports (Gould, 1982).

There are a number of challenges on the road to successes of athletes. These are longlasting and painstaking training sessions, unpleasant rehabilitation after injuries, but also frequent agonies and disappointments after defeat. In order to overcome all these difficulties,

Received May 15, 2019/ Accepted September 03, 2020

Corresponding author: Aleksandra Aleksić Veljković

Faculty of Sport and Physical Education, University of Niš, Čarnojevića 10a, 18000 Niš, Serbia

Phone: + 38118510900 •E-mail: axy.gym@gmail.com 
in addition to talent and good physical preparation, the athlete's psychological stability is also significant (Vallerand \& Losier, 1999).

Research shows that athletes can talk about two main types of motivation: internal or intrinsic (Sun, Li, \& Shen, 2017, according to Karaoglanidis, Mouratidou, Kanellopoulos, Karamavrou, \& Parisi, 2020), and external or extrinsic motivation (Vallerand, Deci, \& Ryan, 1987). Athletes who show inner (intrinsic) motivation enjoy the sports activity and performance itself, and this is what gives them pleasure. For extrinsic, or external motivation, participation in sports is determined by the acquisition of some benefits that can be of a material (e.g. monetary reward) or social nature (e.g. status).

Intrinsic motivation in sports performance best illustrates activities of athletes who are task-oriented, and the successful realization of a certain activity leads to a feeling of satisfaction. The development of intrinsic motivation favors the satisfied psychological needs of the athlete: the experience of autonomy and personal initiative, the experience of competence and the desire for advancement, as well as the sense of connection with the team, which offers them the impetus to succeed and achieve their goal (Vallerand, 2007).

In the case of extrinsic motivation, which is based on external motives and in which orientation of the outcome is dominant, athletes' competences come to the forefront, and in that case they are more important than the way in which the task itself is performed (Walling, Duda, \& Chi, 1993; Fredrick \& Ryan, 1995, according to Cox, 2005). In this case, sports activity itself is perceived as imposed, and the motivation for this activity may be less intense. In a situation where an athlete is focused solely on the outcome of an activity, the assessment of his success is viewed through an external reference framework and he expects a "reward" for the effort involved. The prize in this case means a certain achievement, or "being better" than others.

Throughout the process of motivation, success in sport and the achievement of good results is largely the result of developed internal motivation, but the importance of external motives should not be overlooked.

In addition to this general division of motivation, which is based on the theory of target orientation, we wanted to show other psychological motivation theories.

The aim of this study is to point out the importance of motivation in sport achievement and to describe the psychological aspect of motivation, as one of the most important psychological factors for success.

\section{THEORETICAL CONSIDERATIONS OF THE PROBLEM}

\section{Motivation theories}

\section{Achievement goal theory}

The basis of this theory is the thesis that people experience success differently. Generally, two orientations are recognized: orientation to the task and orientation to the outcome (Ames, 1984; Nicholls, 1984; Dweck, 1986).

Task-oriented people perceive themselves as successful when they make a maximum effort, learn something new, or reach a personal maximum. Their activity has been observed to be more concentrated on the process itself, and less on the outcome. Therefore, athletes with this orientation have an individual target for the task and the improvement of sports skills. On the other hand, outsiders see themselves as successful 
only when they are better than others. With athletes with this orientation we have an individual goal-oriented performance as a result. The difference between these two orientations can be described as a desire for advancement (orientation to a task) and a desire to prove (orientation to the outcome) (Hodge \& Petlichkoff, 2000).

Research (Duda \& Nicholls, 1992; Newton \& Duda, 1999; Duda \& Treasure, 2006) show that two types of target orientation are actually an orthogonal dimension. Therefore, an athlete can be both highly task oriented and low on outcome, and it is also possible to be high or low-oriented both on the task and on the outcome.

Research further shows that athletes with a high outcome orientation and a low orientation to the task tend to develop maladaptive behaviors compared to athletes, who experience the reverse. Maladaptive behaviors include: motive for status, excessive competence, unsportsmanlike attitudes and aggressive behavior. The results of the meta-analytical study (Bidlle, Wang, Kavussan, \& Spray, 2003) indicated a positive relationship between the outcome orientation and the previously described maladaptive behavior. This is especially demonstrated in situations where they lose. Also, there is a positive link between highly expressed orientation to the task and low expressed orientation to the outcome, on the one hand, and adaptive behavior: good teamwork, positive effect on the other.

Research also shows that when an athlete sees a high task orientation, combined with a high outcome orientation, this results in a desirable competitive profile of an athlete who has a strong desire to win, but also a strong motivation to achieve progress, readiness to learn and reach his personal maximum (Roberts, Treasure, \& Kavussan, 1996; Tod \& Hodge, 2001). In this case, the loss of a match is perceived as part of the learning process and the investment of the masculine effort in order to achieve the ultimate goal.

In accordance with the existing theory, what is needed in working with athletes is to strengthen orientation to the task. By developing this orientation, the athlete has the experience of greater control over the situation, which further leads to a reduction of stress and anxiety, and to an increase of intrinsic motivation. Such a psychological state and approach inevitably lead to a greater chance of success.

Work with athletes should certainly include work on changing the definition of success. Instead of seeing success as a victory, a different vision of success is needed - as a process of learning, improving, investing effort to achieve victory. This leads to better coping with failure or injuries.

\section{Attribution theory}

Attribution is the process by which individuals explain the causes of behavior and situation (success/failure). The literature discusses three dimensions of attribution (Weiner, 1985): controllability - the degree of impact that can be expressed above the pattern (whether the person causing the event perceives that it is under their control or not), the causality - whether the person attributes the cause of events to inner or external factors (other people or circumstances), and stability - an estimate of the duration of the cause (whether the person sees the cause of the event as being stable over time or not). In the last decade, there are two more dimensions: globality, if a person sees the cause of events as something that relates to many situations or as something that relates to very specific situations and universality, ie., whether a person perceives the cause as relevant to many people or just to individuals (Rees, Ingledew, \& Hardy, 2005).

The research of Coffee \& Rees $(2008,2009)$ and Allen (2010) shows that the reasons for sporting failure should be considered in the context of events for which internal, 
controllable and unstable factors are responsible. In other words, it is desirable to attribute failure to itself but at the same time regard it as an immediate rather than a lasting state. In doing so, it is important to show a readiness to appreciate that a different approach may yield different results.

When it comes to success, it needs to be explained by internal, controllable and stable factors, i.e. success is desire to attribute to yourself and believe that with good access, success will be sustained. It is considered that for success in sports, it is much more important that an athlete experiences failure, and in dealing with it, it is necessary to emphasize the attitude towards failure.

In the process of training and competition, it is important to teach athletes to take on personal responsibility, both for their successes and for their failures. This is the way in which the athletes strengthen their personal sense of control over the situation, which then leads to an increase in internal motivation.

\section{Self-efficacy theory}

Self-efficacy theory perceives sports efficiency in interaction with the environment and it is a decisive factor in behavior change. This theory has several key assumptions. Bandura $(1986,1997)$ points to six factors that are crucial in the experience of the self-efficacy of each athlete: previous experience, vicarious learning, positive verbal messages by other important physiological and emotional states of the athlete, visualization of success.

If an athlete has previously experienced success, he will expect the same in the future. Also, if an athlete watches another athlete successfully carrying out a particular movement, that experience will have a positive impact on the experience of self-efficacy. The impact will be greater if the observed model is similar to the observer (by age, gender, ability, etc.). Further, if the athlete is exposed to positive verbal messages (instructions or motivational sentences) from significant people, he will experience himself as being effective. The physiological state also plays an important role. Due to the connection between mind and body, the assessment of self-efficacy affects whether the athlete is tired or excited. In situations where excitement is emphasized, thoughts are oriented toward failure. In addition to the physiological state, there is the emotional state in which an athlete finds himself influenced by the experience of self-efficacy. Emotions and thoughts are connected, and even emotional states like frustration or anger can negatively affect the assessment of the athlete's selfefficacy. In the end, the visualization of success (the athlete imagines himself doing a successful task) also positively influences the assessment of self-efficacy.

In a meta-analytical review, Moritz, Feltz, Fahrbach and Mack (2000) report a positive link between self-efficacy and success. Nevertheless, Schmidt and DeShon (2009) warn of the danger of over-estimation and self-assessment of self-efficacy. If an athlete overwhelmingly believes in his success, he will invest less time and energy into exercise, which will result in less success.

Feltz, Short, \& Sullivan (2008) describe several methods for increasing self-efficacy in athletes:

- Modeling - an athlete focuses on a model that produces desirable behavior. The model can be ideal (a professional in a particular sport or skill) or similar athletes who carry out certain skills in an adequate way. It also often happens that an athlete achieves better results if the model is more similar to his own because the identification process is easier;

- Setting appropriate goals; 
- Recording past success - this method reminds the athlete of what he is able to achieve and has a favorable effect on the increase in self-efficacy. The realization of this method is possible through imagination or watching videos;

- Optimistic thinking and self-confident behavior;

- Being surrounded by people who are supportive.

\section{Self-determination theory}

According to this theory (Deci \& Ryan, 1985, 1991) intrinsic motivation will exist with an athlete when three main psychological needs are satisfied: competence, connectivity and autonomy. Competence refers to the subjective experience of an individual that can achieve success. A relationship implies a sense of belonging and acceptance by significant people. Autonomy is the need to experience one's own behavior as freely chosen and not imposed by others.

Research shows that athletes with a high level of self-determination (a strong experience of competence, connectivity and autonomy) have better sporting performances than athletes with a low level of self-determination (Gillet, Berjot, \& Gobance, 2009).

Increasing the sense of competence of an athlete is achieved by pointing out to athletes that they can control the causes that lead him to success. For a better connection experience, it is important to focus on building the best possible relationship between athletes and trainers, as well as between athletes and other team members. The experience of the autonomy of an athlete is left in such a way that no pressure is exerted by the coaches, teammates or others from the immediate environment.

\section{Expectancy value theory}

According to this theory, what defines success is the belief that success will be achieved (expectations), and the assessment of the importance (value) of success for a particular person. For example, one can believe in his success, but he lacks the desire to achieve it. On the other hand, one may be highly interested, but does not believe in his ability to achieve success. In both cases, good results are missing.

Wigfield, \& Eccles (2020) state that the subjective value defines four components: importance (value of achievement), interest (intrinsic value), usefulness (utilitarian value) and prices (perceived cost). The importance (value of achievement) refers to how many people estimate that it is worth the success on a particular task. Interest (intrinsic value) represents the level of satisfaction of a person because of being engaged in a particular task. Usability (utilitarian value) implies how the performance of a specific task can help a person achieve the short-term and long-term goals. The price (perceived cost) refers to the assessment of the effort to satisfy a specific task, the assessment of restrictions in the choices of other activities, and the psychological assessment of potential failure in the task.

In a situation where an athlete believes in his skills but lacks motivation, it is necessary to find individual value in further sports activities. If despite the effort an athlete can no longer find value, then withdrawal is considered.

\section{Motivation techniques}

A number of techniques are used to motivate athletes. The three most commonly used ones include: goal setting, cognitive restructuring and imagination. 
Setting goals

The main source of motivation are the goals set by the athletes. However, it is very important that goals are adequately formulated. When it comes to this topic, the so-called. SMART model defines the necessary characteristics of the defined goal (Doran, 1981). The main characteristics of the goal are to be: S - (specific), concrete, clear; M - (Measurable) measurable result, it can be checked whether and to what extent the goal is achieved; A (achievable), achievable with the available resources at a given time; $\mathrm{R}$ - relevant, relevant to contribute to the realization of the vision; $\mathrm{T}$ - (time constrained) has the definite final time for realization.

The aim is to say that it is specific when it is clearly defined and fully understandable. This implies answering three questions: how, why, and what? This specifies what is meant to be achieved, how this is planned and what the motive is. If the goal requires the engagement of more people, it is necessary to define precisely who they are and what their tasks are.

The second characteristic, the measurability of the goal, refers to the criterion based on which an individual will know whether and how the achievement of the goal is progressing. For example, it is not clear what exactly good sport success for a current year means. How will an athlete know at the end of the year whether his success was good or not? How is the success measured? If the goal relates to the team and is not measurable, then everyone has the freedom to interpret what is good for anyone, whether success was good at the annual level or not. In such situations, it is necessary to define a goal that will answer the question - how much? For example. The goal is to achieve at least 30 wins in the season.

The third characteristic of the goal is to be achievable. Therefore, it is important to know your boundaries and therefore avoid potential underestimation or overestimation of yourself. This would mean that goals should not be defined as something that is realistic in itself, without much effort, because then the goals are not motivating and do not contribute to development. They need to be ambitious and their realization to require additional effort, but at the same time they should not go beyond the capabilities and skills of the individual / team. In order to make this step well, it is important to recall the previous experience. For this goal planning segment, it is important to be flexible, ie., it is okay if the goal changes, if the need arises for the team. For example, the goal "stay in the first league this year." can be revised after a while. If the team succeeds and no longer remains in the first league, the goal can be redefined, for example: "Be among the top eight teams at the end of the season."

The goal is relevant when it actively contributes to achieving predefined visions. If the goal is not related to the ultimate vision to be achieved, then it is considered irrelevant.

When not defined outwardly, it is important to set a time limit until the target is achieved. And it is important to be aware of your possibilities. It is not good to allow too much time because the goal will be lost in the sea of other obligations, but insufficient time is not a solution because it will not be achieved in that time.

An example of a well-defined goal would be: we want to win this year's medal at the national championship. If the team showed a good result last year, then the goal formulated like this is relevant, achievable but also specific, measurable and time-limited.

\section{Cognitive restructuring}

Another important technique is to change the irrational beliefs of athletes, whether it be the beliefs about coaching or the beliefs about their performance (successes/failures). This 
technique is based on the premise of Cognitive-Behavioral Therapies according to which there are no events that affect how we feel and behave but our interpretation of these events (Beck, 2011). When a person irrationally interprets certain aspects of the situation, this leads to unhealthy emotions and dysfunctional behavior. When, in a rational way, a person sees the events or aspects of these events, it stimulates healthy emotions and functional behavior. Therefore, it is important to work with athletes to identify irrational beliefs and to replace them with rational beliefs, which in turn leads to healthy emotions and functional behavior. Examples of irrational beliefs are: "I will never succeed!", "I suffered defeat. I am not in this sport.","I have to win the championship!","I cannot stand defeat." Rational versions of the previous beliefs are: "Success requires effort and investment. The results are not achieved immediately, I progress gradually."; "Defeat does not define me as a player."; "I would very much like to win the championship, but that does not mean that I have to. I will try to give my maximum."; "I'm not comfortable when I experience a defeat, but I can certainly handle it. Moreover, it can serve as a good lesson. "

\section{Imagination}

Imaginations are included in common techniques used with athletes in order to increase motivation and achieve good results. What is important for imagination is that it is necessary to refer to images that include all the senses (sight, hearing, taste, smell, touch, etc.) in order to be a more graphic experience for the brain. It is important that a person conceives that a particular movement is successfully carried out (Montuori et al., 2018).

There are two variants of imagination. Internal imagination implies that a person, from a personal perspective, imagines himself performing the movement successfully. External imagination implies that an athlete sees himself from the perspective of other people, as if watching himself on television. The experience of virtual success increases self-confidence, which further leads to increased motivation (Montuori et al., 2018).

\section{The role of a coach in the motivational climate}

The behavior of the coach is most desirable for the motivation of an athlete (Vallerand \& Losier, 1999). It is considered that the most important interpersonal relationship that is created in sports is the connection between the coach and the athlete. This connection is important because it significantly affects not only the sports performance (Horn \& Carron, 1985), but also the experience of the athletes' pleasure (Challadurai, 1993). For example, research results aimed at examining interpersonal relationships between coaches and athletes have shown that a positive perception of attitudes with a coach by athletes is more important than a high intrinsic motivation and focus on achievement (Vallerand \& Losier, 1999).

The basic point of view is, when the athletes' motivation is concerned, that the behavior of the coach can have a significant impact on the athlete's motivation, because it depends on his experience of competence, autonomy and sense of belonging.

It turned out that coaches working with athletes develop two different behaviors. One is called a controlling style and the other autonomous - or supporting. Coaches who nurture a controlling style of behavior in interaction with athletes foster a highly directive style of communication (for example, "You'll play like I tell you; otherwise you will still be sitting on the bench!"). On the other hand, coaches who nurture autonomy and a supportive style will leave the players room for independent decisions (e.g. "We have three different strategies, and during the match, you will evaluate which is the most appropriate for the given situation."). Research in this field shows that in athletes whose coaches use the autonomous - supporting 
style observed a higher level of indicative motivation compared to those athletes whose coaches cherish the controlling style (Deci, Nezlek, \& Sheinman, 1981). The next research in this field confirms this finding. Exploring the motivation of a university swimmer's club, it was noticed that swimmers whose coach fostered a controlling style, during the competition show a significantly lower degree of intrinsic motivation (Pelletier, Tuson, \& Green-Demers, 1998). On the contrary, fostering an autonomous - supportive style by the trainer leads to the experience of competence, autonomy and sense of belonging to athletes. Athletes with an experience of competence, autonomy and sense of belonging show greater motivation for achieving success, and they are seen higher on the level of intrinsic motivation (Blanchard and Vallerandar, 1999b).

One of the main tasks of the trainer is to create a positive motivating environment that is task oriented, i.e. leads to skills development. Such an approach to an athlete creates a sense of satisfaction. The climate, in which the orientation towards the achievement of a particular goal dominates, creates pressure and tension among athletes, especially in the younger ones, which can adversely affect their further interest and experience of pleasure in sports (Abernethy, Hanrahan, Kippers, Mackinnon, \& Pandy, 2012).

In addition to the fact that personal success in sports is observed differently, it is conditioned by age. At a younger age, it is measured in relation to previous achievements. Later, at the elementary school age, success is measured in comparison with other children, i.e. ego orientation develops. With the advent of adolescence, one can expect young people to display one of these two orientations, in sports achievement depending on the situation (Duda, 1987). We should not neglect social factors, above all the interpersonal relations between the athletes themselves, as well as between athletes and coaches. It is important that friends of the club maintain friendly relations and that the talented individuals do not "rise" to the star. It happens that talented children are physically superior because their development is faster than others', and therefore, they achieve better results in sports. They are often paid more attention to, while other athletes become neglected by the coaches.

Regardless of whether it is an individual or group sport, it is desirable that the coach defines the concept of success for each individual. Each of them needs a personal promotion, not a win in the competition. If victory is taken as a criterion of success, at each competition there will be a large number of unsuccessful and far fewer successful ones. Repeated failure leads to a weakening of motivation and abandonment of sport. What is needed for a coach to be rewarded by his athletes is effort, commitment, desirable behaviors, and "fair play", responsibility, perseverance, perseverance.

It is important that the coach creates a climate that will ensure that all athletes they feel equally important and are provided with conditions for developing personal competence, which is a requirement for every sporting success.

\section{CONCLUSION}

When it comes to motivation in sports, some important concepts and some of the most important interventions for motivating athletes presented in this paper can be considered in the psychological training of athletes. Special attention given to the importance and the role of trainers in the process of motivating athletes emphasizes psychology as a key factor in sport achievement. 


\section{REFERENCES}

Allen, M.S. (2010). On the temporal dynamics of causal attribution in competitive sport. International Review of Sport \& Exercise Psychology, 3, 3-23.

Ames, C. (1984). Achievement attributions and self-instructions under competitive arid individualistic goal structures. Journal of Educational Psychology, 76(2), 478-487.

Abernethy, B., Hanrahan, S.J., Kippers, V., Mackinnon, L.T., \& Pandy, M.G. (2012). The biophysical foundations of human movement, $3^{r d}$ Ed. Human Kinetics.

Bandura, A. (1986). Social foundations of thought and action: A social cognitive theory. Englewood Cliffs, NJ: Prentice Hail.

Bandura, A. (1997). Self-efficacy: The exercise of control. New York: Freeman.

Beck, J.S. (2011). Cognitive behavior therapy: Basics and beyond, 2nd Ed. New York, NY, US: Guilford Press.

Biddle, S., Wang, C., Kavussanu, M., \& Spray, C. (2003). Correlates of achievement goal orientations in physical activity: a systematic review of research. European Journal of Sport Science, 3(5), 1-20.

Blanchard, C., \& Vallerand, R.J (1996b). Perceptions of competence, self-efficacy and intrinsic interest as psychological mediators of the social-factors - contextual motivation relationship. Unpublished manuscript. Université du Québec à Montréal.

Chelladurai, P. (1993). Leadership. In R.N. Singer, M. Murphey, \& L.K. Tennant (Eds.), Handbook of research on sport psychology, (pp. 647-671). New York: Macmillan.

Coffee, P., \& Rees, T. (2008). Main and interactive effects of controllability and generalizability attributions upon self-efficacy. Psychology of Sport \& Exercise, 9, 775-785.

Coffee, P., \& Rees, T. (2009). The main and interactive effects of immediate and reflective attributions upon subsequent self-efficacy. European Journal of Sport Science, 9(1), 41-52.

Cox, H.R. (2005). Psihologija sporta (Psychology of sport). Zagreb: Naklada Slap. In Croatian

Deci, E.L., \& Ryan, R.M. (1985). Intrinsic motivation and self-determination in human behavior. New York: Plenum.

Deci, E.L., Nezlek, J., \& Sheinman, L. (1981). Characteristics of the rewarder and intrinsic motivation of the rewarded. Journal of Personality and Social Psychology, 40(1), 1-10.

Deci, E.L., \& Ryan, R.M. (1991). A motivational approach to the self: Integration in personality. In: R. Dientsbier (Ed.), Nebraska Symposium on Motivation: Vol. 38. Perspectives on motivation, (pp. 237-288). Lincoln: University of Nebraska Press.

Doran, G.T. (1981). There's a S.M.A.R.T. way to write management's goals and objectives. Management Review. 70 (11), 35-36.

Duda, J.L. (1987). Toward a developmental theory of children's motivation in sport. Journal of Sport Psychology, 9, 130-145.

Duda, J.L., \& Nicholls, J.G. (1992). Dimensions of achievement motivation in school-work and sport. Journal of Educational Psychology, 84(3), 290-299.

Duda, J.L., \& Treasure, D.C. (2006). Motivational processes and the facilitation of performance, persistence, and well-being in sport. In: J.M. Williams (Ed.), Applied sport psychology: Personal growth to peak performance, 5th Ed., (pp. 57-81). New York: McGraw-Hill.

Dweck, C.S. (1986). Motivational processes affecting learning. American Psychologist, 41, 1040-1048.

Feltz, D.L, Short, S.E., \& Sullivan, P.J. (2008). Self-efficacy in sport: Research and strategies for working with athletes, teams, and coaches. Champaign, IL: Human Kinetics.

Frederick, C.M. \& Ryan, R.M. (1995). Self-determination in sport: A review using cognitive evaluation theory. International Journal of Sport Psychology, 26, 5-23.

Gillet, N., Berjot, S., \& Ciobance, L. (2009). A motivational model of performance in the sport domain. European Journal of Sport Science, 9, 151-158.

Gould, D. (1982). Sport in psychology in the 1980's: Status, direction and challenge in your Sports research. Journal of Sport Psychology 4, 203-218.

Gould D., Dieffenbach, K., \& Moffett, A. (2002). Psychological characteristics and their development in Olympic champions. Journal of Applied Sport Psychology. 14(3), 172-204.

Hodge, K., \& Petlichkoff, L. (2000). Goal profiles in sport motivation: A cluster analysis. Journal of Sport \& Exercise Psychology, 22, 256-272.

Horn, T.S., \& Carron, A.V. (1985). Compatibility in coach-athlete relationships. Journal of Sport Psychology, 7, 137-149.

Karaoglanidis, D., Mouratidou, K., Kanellopoulos, P., Karamavrou, S., \& Parisi, I. (2020). Perceived autonomy, motivation climate and intention for physical activity. A comparative study of students based on their gender and educational level. Facta Universitatis Series Physical Education and Sport, 18(1), 25-36. 
Montuori, S., Curcio, G., Sorrentino, P., Belloni, L., Sorrentino, G., Foti, F., et al. (2018). Functional role of internal and external visual imagery: Preliminary evidences from pilates. Neural Plasticity, https://doi.org/10.1155/2018/ 7235872 .

Moritz, S.E., Feltz, D.L., Fahrbach, K.R., \& Mack, D.E. (2000). The relation of self-efficacy measures to sport performance: A meta-analytic review. Research Quarterly for Exercise and Sport, 71(3), 280-294.

Newton, M., \& Duda, J.L. (1999). The interaction of motivational climate, dispositional goal orientations, and perceived ability in predicting indices of motivation. International Journal of Sport Psychology, 30, 63-82

Nicholls, J.G. (1984). Achievement motivation: Conceptions of ability, subjective experience, task choice, and performance. Psychology Review, 91(3), 328-346.

Pelletier, L., Tuson, K., \& Green-Demers, I. (1998). Why are you doing things for the environment? The motivation toward the environment scale (MTES). Journal of Applied Social Psychology, 28, 437-468

Rees, T., Ingledew, D.K., \& Hardy, L. (2005). Attribution in sport psychology: Seeking congruence between theory, research and practice. Psychology of Sport and Exercise, 6, 189-204.

Roberts, G.C., Treasure, D.C., \& Kavussanu, M. (1996). Orthogonality of achievement goals and its relationship to beliefs about success and satisfaction in sport. The Sport Psychologist, 10, 398-408.

Schmidt, A.M., \& DeShon, R.P. (2009). Prior performance and goal progress as moderators of the relationship between self-efficacy and performance. Human Performance, 22, 191-203.

Sun, H., Li, W., \& Shen, B. (2017). Learning in physical education: A self-determination theory perspective. Journal of Teaching in Physical Education, 36(3), 277-291.

Tod, D., \& Hodge. K. (2001). Moral reasoning and achievement motivation in sport: A qualitative inquiry. Journal of Sport Behavior, 24, 307-327.

Vallerand, R.J., Deci, E.L., \& Ryan, R.M. (1987). Intrinsic motivation in sport. Exercise and Sport Sciences Review, 15, 389-425.

Vallerand, R.J., \& Losier, G.F. (1999). An integrative analysis of intrinsic and extrinsic motivation in sport. Journal of Applied Sport Psychology, 11(1), 142-169.

Vallerand, R.J. (2007). Intrinsic and extrinsic motivation in sport and physical activity. In: G. Tenenbaum, \& R.C. Eklund (Eds.), Handbook of sports psychology, (pp. 59-80). Hoboken, NJ: John Wiley \& Sons, Inc.

Walling, M.D., Duda, J.L., \& Chi, L. (1993). The perceived motivational climate in sport questionnaire: Construct and predictive validity. Journal of Sport \& Exercise Psychology, 15(2), 172-183.

Weiner, B. (1985). An attributional theory of achievement motivation and emotion. Psychological Review, 92(4), 548-573.

Wigfield, A., \& Eccles, J.S. (2020). 35 years of research on students' subjective task values and motivation: A look back and a look forward. In: Advances in motivation science, Vol. 7, (pp. 161-198). Elsevier.

Wilson, P., \& Rodgers, W. (2004). The relationship between perceived autonomy support, exercise regulations and behavioral intentions in women. Psychology of Sport and Exercise, 5(3), 229-242.

\section{PSIHOLOŠKI ASPEKTI MOTIVACIJE U SPORTSKIM OSTVARENJIMA}

Cilj ovog rada je da ukaže na važnost motivacije u sportskim ostvarenjima i da opiše psihološki aspekt motivacije, kao jednog od najvažnijih psiholoških faktora uspeha. Teorije motivacije daju definicije pojmova i prethodnih znanja različitih autora, a drugi deo ovog rada daje najčešće korišćene tehnike: postavljanje ciljeva, kognitivno restrukturiranje i maštu $i$ kako ih primeniti. Kada je reč o motivaciji u sportu, neki važni koncepti $i$ neke od najvažnijih intervencija za motivisanje sportista predstavljeni u ovom radu mogu da se uzmu u obzir u psihološkom treningu sportista. Posebna pažnja posvećena značaju i ulozi trenera u procesu motivisanja sportista ističe psihologiju kao ključni faktor u sportskim ostvarenjima.

Ključne reči: psihologija, motivacija, teorije, sportisti, treneri, uspeh u sportu 